\title{
Preparation of titanium diboride powders from titanium alkoxide and boron carbide powder
}

\author{
HAMED SINAEI POUR FARD* and HAMIDREZA BAHARVANDI \\ Department of Materials and Manufacturing Process, Malek Ashtar University of Technology, Tehran \\ 15875-1744, Iran
}

MS received 11 April 2010; revised 18 May 2010

\begin{abstract}
Titanium diboride powders were prepared through a sol-gel and boron carbide reduction route by using TTIP and $\mathrm{B}_{4} \mathrm{C}$ as titanium and boron sources. The influence of TTIP concentration, reaction temperature and molar ratio of precursors on the synthesis of titanium diboride was investigated. Three different concentrations of TTIP solution, $\mathbf{0 \cdot 0 3 3 / 0 \cdot 0 5 / 0 \cdot 1}$, were prepared and the molar ratio of $B_{4} C$ to TTIP varied from 1.3 to $2 \cdot 5$. The results indicated that as the TTIP concentration had an important role in gel formation, the reaction temperature and $\mathrm{B}_{4} \mathrm{C}$ to TTIP molar ratio showed obvious effects on the formation of $\mathrm{TiB}_{2}$. Pure $\mathrm{TiB}_{2}$ was prepared using molar composition of $\mathrm{Ti}: \mathrm{B}_{4} \mathrm{C}=1: 2 \cdot 3$ and the optimum synthesis temperature was $1200^{\circ} \mathrm{C}$.
\end{abstract}

Keywords. Titanium diboride; sol-gel; boron carbide; reduction; TTIP.

\section{Introduction}

Titanium diboride is a hard refractory material with a high melting point, low electrical resistivity and high thermal conductivity (Kim and McMurtry 1985). In addition, sintered $\mathrm{TiB}_{2}$ is resistant to oxidation up to $1100^{\circ} \mathrm{C}$ and chemically stable in many harsh, corrosive environments (Greenwood 1973). $\mathrm{TiB}_{2}$ has also low solubility and is wetted by most molten metals up to $1000^{\circ} \mathrm{C}$. The combination of these properties makes $\mathrm{TiB}_{2}$ a very interesting engineering ceramic material which can be used as ballistic armor, coatings for cutting tools (Funk et al 1973), crucibles and electrodes in metal refining equipments such as aluminum reduction cells (Murata and Miccioli 1971).

$\mathrm{TiB}_{2}$ can be prepared by carbothermic reduction of mixed oxides of boron and titanium, reduction of titanium oxide by boron carbide and carbon, reduction of mixed oxides by metals like aluminum, silicon, magnesium, etc. $\mathrm{TiB}_{2}$ can also be synthesized from the elements by heating, mechanical alloying or self-propagating high temperature synthesis (SHS) (Matkovich 1977; Radev 1996; Weimer 1997; Ge and Ye 2002; Hwang 2002; Krishnarao and Subrahmanyam 2003).

Sol-gel technique has been widely used for the manufacturing of nano-phased powders such as metal oxides and ceramics. In the process, reactive metal precursors were initially hydrolyzed, followed by condensation and

\footnotetext{
*Author for correspondence (hamed.sinaie@gmail.com)
}

polymerization reactions. Metal alkoxides are metalorganic compounds having an organic ligand attached to a metal or metallic atom. Because of the synthesis from atomic or molecular precursors, sol-gel technique can give better control of particle size and homogeneity in particle distribution (Cushing 2004; Tjong and Chen 2004). This work demonstrates the formation of $\mathrm{TiB}_{2}$ by sol-gel method using a mixture of titanium tetra isopropoxide (TTIP) and boron carbide as precursor materials.

\section{Experimental}

The starting materials for preparation of $\mathrm{TiB}_{2}$ were synthesized by hydrolyzing titanium tetra isopropoxide $\left(\mathrm{Ti}\left[\mathrm{OCH}\left(\mathrm{CH}_{3}\right)_{2}\right]_{4}, 97 \%\right.$ purity, Alfa Aesar) with four molar equivalents of distilled water in IPA solvent (Isopropyl Alcohol, $\mathrm{C}_{6} \mathrm{H}_{5} \mathrm{OH}, 99 \%$ purity) under vigorous stirring. Three different TTIP concentrations in IPA were prepared: $0.033,0.050$ and $0.1 \mathrm{M}$. The $\mathrm{B}_{4} \mathrm{C}: \mathrm{Ti}: \mathrm{H}_{2} \mathrm{O}$ molar ratio of the starting material was $x: 1: 4$, where $x$ varied from $1 \cdot 3$ to $2 \cdot 5$. The resulting dark suspension was stirred for $105 \mathrm{~min}$ at room temperature, the volatile components were removed under vacuum at $140^{\circ} \mathrm{C}$. The powder then was heat treated at $900-1200^{\circ} \mathrm{C}$ in a graphite crucible in $1 \mathrm{~atm}$ argon. The phase analysis of the synthesized powders was carried out by an X-ray diffractrometer (Simens D500, Germany) with $\mathrm{CuK} \alpha$ $(\lambda=1.540598 \AA)$ radiation. Morphology of the powders was analyzed by scanning electron microscope (Camscan MV2300, $27.0 \mathrm{kV}$ ). 


\section{Results and discussion}

Science alkoxides of transition metals are highly reactive to water, TTIP precursor can readily react with water via the following reaction to form titanium hydroxide (Levin 1999). According to the high positive charges on the metal of the complex, the rate of hydrolysis is very rapid and nonstable titanium hydroxide converted to titanium dioxide as the reaction proceeded in time

$$
\begin{aligned}
& \mathrm{Ti}\left[\mathrm{OCH}\left(\mathrm{CH}_{3}\right)_{2}\right]_{4}+4 \mathrm{H}_{2} \mathrm{O}=\mathrm{Ti}(\mathrm{OH})_{4}+4 \mathrm{C}_{3} \mathrm{H}_{7} \mathrm{OH}, \\
& \mathrm{Ti}(\mathrm{OH})_{4}=\mathrm{TiO}_{2}+2 \mathrm{H}_{2} \mathrm{O} .
\end{aligned}
$$

In the case of a solution containing a given concentration of precursors, when hydrolysis occurred, the content of the $\mathrm{Ti}(\mathrm{OH})_{4}$ gradually increased with time. When the solution reached its minimum concentration for nucleation, nuclei appeared and grew. This caused the solute concentration to level off and to start decreasing. If the concentration of solute falls below the minimum level for nucleation, growth takes place exclusively.

The finer particles of $\mathrm{Ti}(\mathrm{OH})_{4}$ resulted from the solution containing 120 TTIP in the range of $0 \cdot 050-0 \cdot 10 \mathrm{M}$. Since heterogeneous nucleation is energetically favoured, in general, this process starts at a lower concentration than that of homogeneous nucleation. The surface of the $\mathrm{B}_{4} \mathrm{C}$ powders, which were dispersed in the solution, may act as nucleation sites. In the case of concentration which was higher than the minimum value for homogeneous nucleation, the $\mathrm{Ti}(\mathrm{OH})_{4}$ phase nucleated separately on the $\mathrm{B}_{4} \mathrm{C}$ powder surfaces, resulting in a mixture of $\mathrm{B}_{4} \mathrm{C}$ and

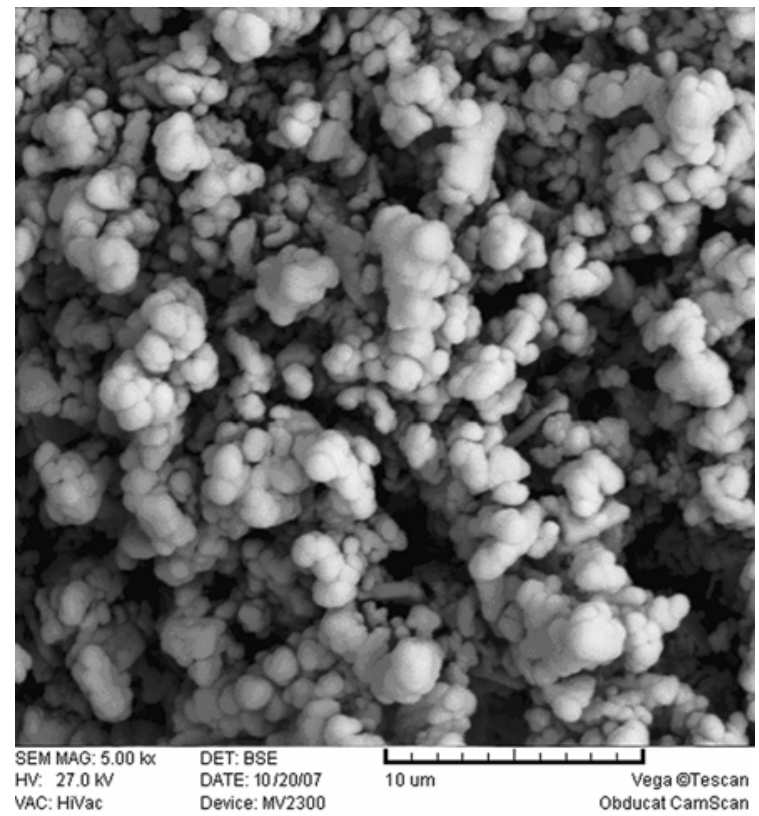

Figure 1. SEM image of homogenous nucleation of $\mathrm{Ti}(\mathrm{OH})_{4}$ phase and mixture of $\mathrm{B}_{4} \mathrm{C}$ and $\mathrm{Ti}(\mathrm{OH})_{4}$ particles for $0.1 \mathrm{M}$ TTIP.
$\mathrm{Ti}(\mathrm{OH})_{4}$ particles. As a result, the concentration of $0 \cdot 050-0 \cdot 10 \mathrm{M}$ TTIP must have been in the range for homogeneous nucleation.

Figure 1 shows the morphology of the sample with the concentration of TTIP in maximum value, $0 \cdot 1 \mathrm{M}$. Obviously, the homogenous nucleation of $\mathrm{Ti}(\mathrm{OH})_{4}$ phase occurred and the $\mathrm{Ti}(\mathrm{OH})_{4}$ phase nucleated separately from the $\mathrm{B}_{4} \mathrm{C}$ powder surfaces, so a mixture of $\mathrm{B}_{4} \mathrm{C}$ and

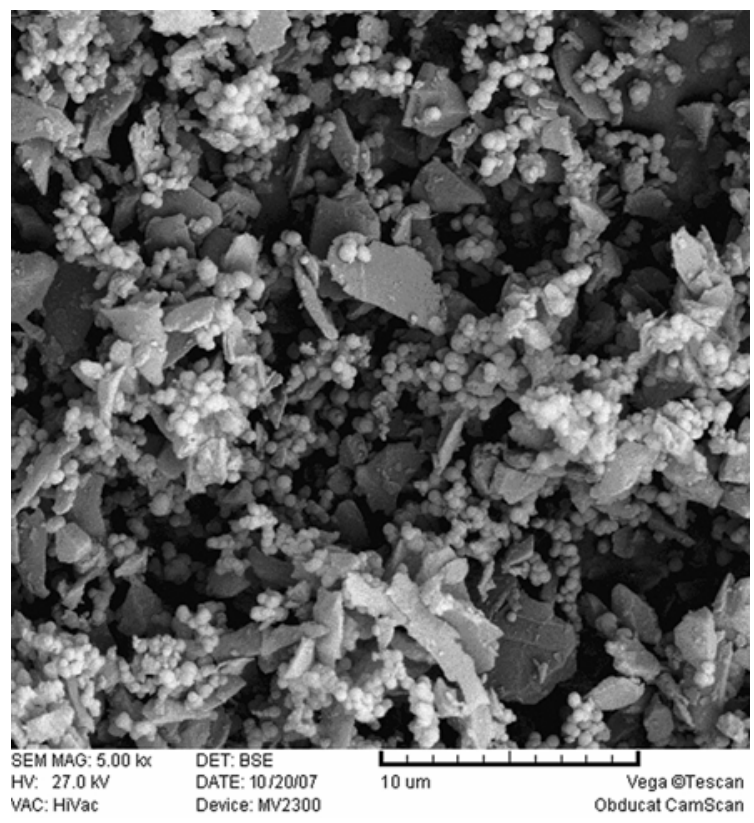

Figure 2. SEM image of homogenous and heterogeneous nucleation of spherical $\mathrm{Ti}(\mathrm{OH})_{4}$ particles that were mainly formed on the $\mathrm{B}_{4} \mathrm{C}$ powder surfaces for $0.05 \mathrm{M}$ TTIP.

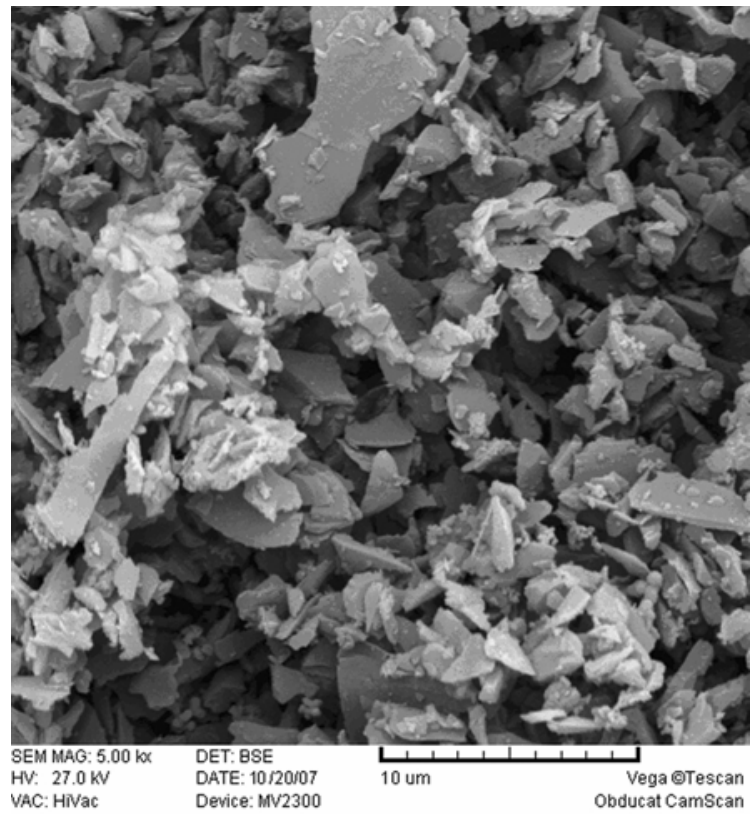

Figure 3. The low TTIP concentration did not cause nucleation of spherical $\mathrm{Ti}(\mathrm{OH})_{4}$ powders during hydrolyze process. 
$\mathrm{Ti}(\mathrm{OH})_{4}$ particles were observed. As the concentration of TTIP decreased to $0.05 \mathrm{M}$, the nucleation of $\mathrm{Ti}(\mathrm{OH})_{4}$ phase was partly homogenous and partly heterogeneous and spherical $\mathrm{Ti}(\mathrm{OH})_{4}$ particles mainly formed at the surface of the $\mathrm{B}_{4} \mathrm{C}$ powders (figure 2). When the concentration of TTIP was less than $0.05 \mathrm{M}$, formation of spherical $\mathrm{Ti}(\mathrm{OH})_{4}$ particles were not observed (figure 3 ).

As indicated in figure 4 , the spherical particle size of titanium hydroxide was less than $100 \mathrm{~nm}$.

$\mathrm{TiO}_{2}$ can be reduced by carbon in the boron carbide phase according to the following reactions

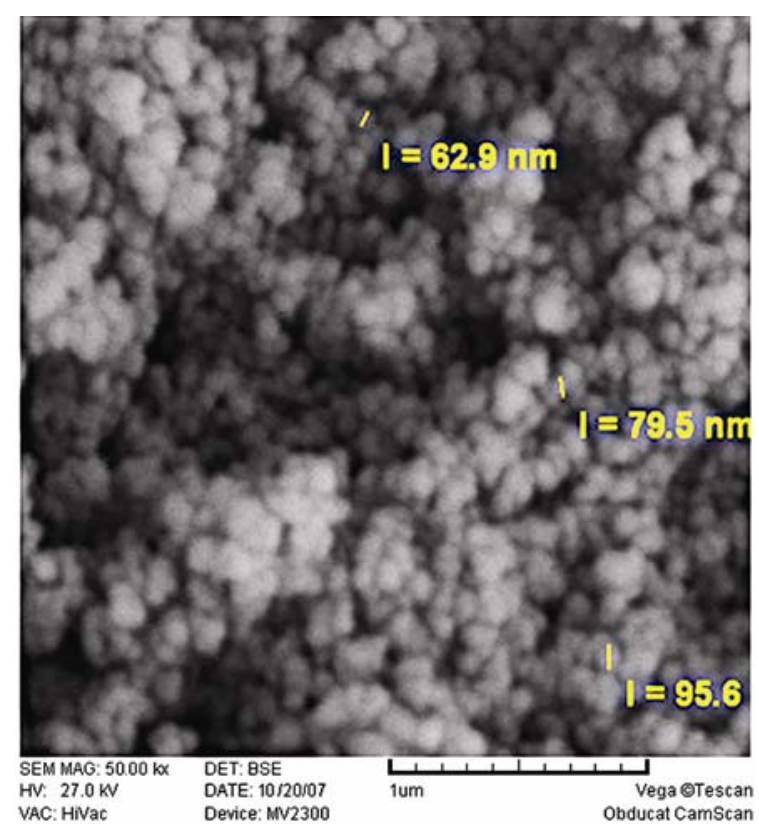

Figure 4. SEM image of $\mathrm{Ti}(\mathrm{OH})_{4}$ particles and its particle size after hydrolyze process.

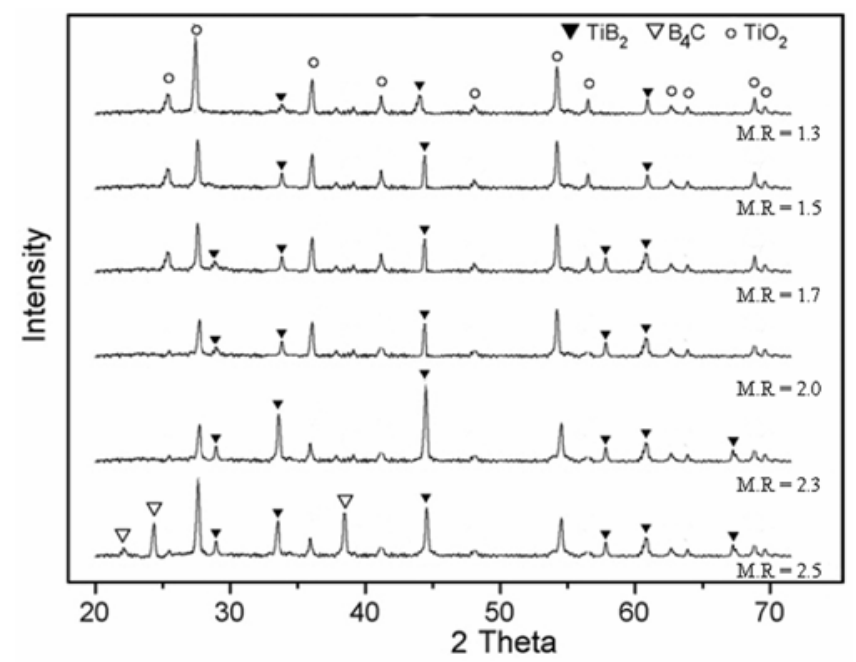

Figure 5. $\mathrm{XRD}$ patterns of $\mathrm{TiB}_{2}$ synthesized at $1100^{\circ} \mathrm{C}$ with various molar ratio of $\mathrm{B}_{4} \mathrm{C}$ to TTIP.

$$
\begin{aligned}
B_{4} C+\frac{2 x}{3+x} \mathrm{TiO}_{2}= & \frac{2 x}{3+x} \mathrm{TiB}_{2}+\frac{2 x}{3+x} \mathrm{CO}_{2} \\
+ & \frac{3 x}{3+x} B_{4} C_{1-x}, \\
B_{4} C+\frac{2 x}{3+x} \mathrm{TiO}_{2}= & \frac{2 x}{3+x} \mathrm{TiB}_{2}+\frac{4 x}{3+x} \mathrm{CO} \\
& +\frac{3 x}{3+x} B_{4} C_{1-x} .
\end{aligned}
$$

The equilibrium parameters for the reduction of $\mathrm{TiO}_{2}$ by carbon originating from the boron carbide phase and thermodynamic analysis were calculated and reported by Levin et al (1999). The amounts of $\mathrm{TiB}_{2}$ in the final product and consumption of all reactants depend obviously on the amount of $\mathrm{TiO}_{2}$ that was added, here TTIP, the source of $\mathrm{TiO}_{2}$.

In the XRD pattern of the sample with the $\mathrm{B}_{4} \mathrm{C}$ to TTIP molar ratio of $1 \cdot 3$, only the $\mathrm{TiO}_{2}$ peaks and main peaks of $\mathrm{TiB}_{2}$ can be seen. Analysis of these peaks by X-powder software showed $5 \cdot 6 \%$ wt. of $\mathrm{B}_{4} \mathrm{C}$ and $16 \cdot 8 \%$ wt of $\mathrm{TiB}_{2}$.

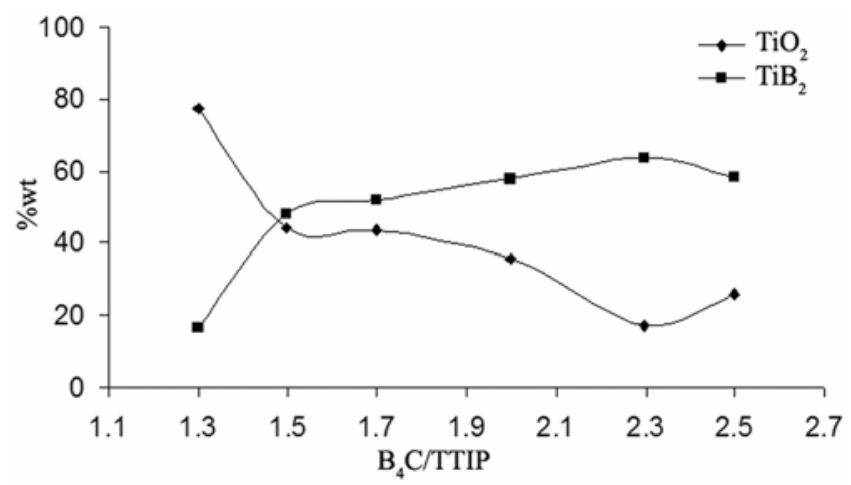

Figure 6. Effects of $\mathrm{B}_{4} \mathrm{C}$ to TTIP molar ratio on weight percent of $\mathrm{TiO}_{2}$ and $\mathrm{TiB}_{2}$ heat treated at $1100^{\circ} \mathrm{C}$.

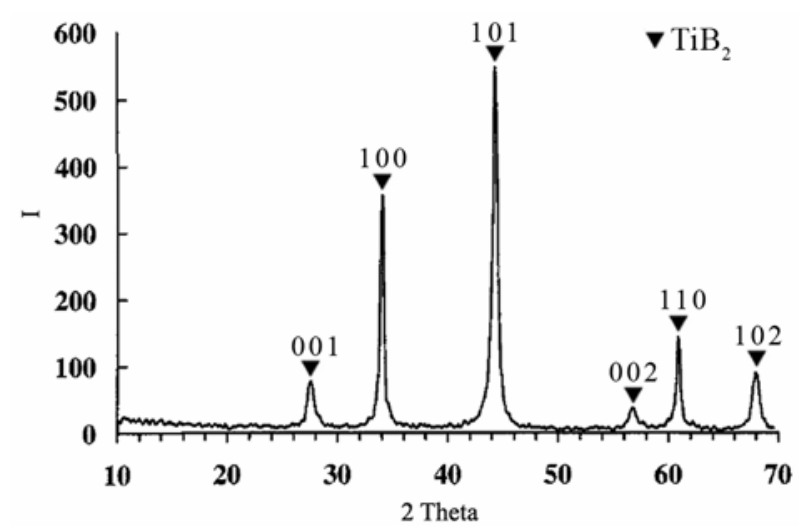

Figure 7. XRD pattern of the sample with the molar ratio of $2 \cdot 3$ heat treated for $1 \mathrm{~h}$ at $1200^{\circ} \mathrm{C}$. 


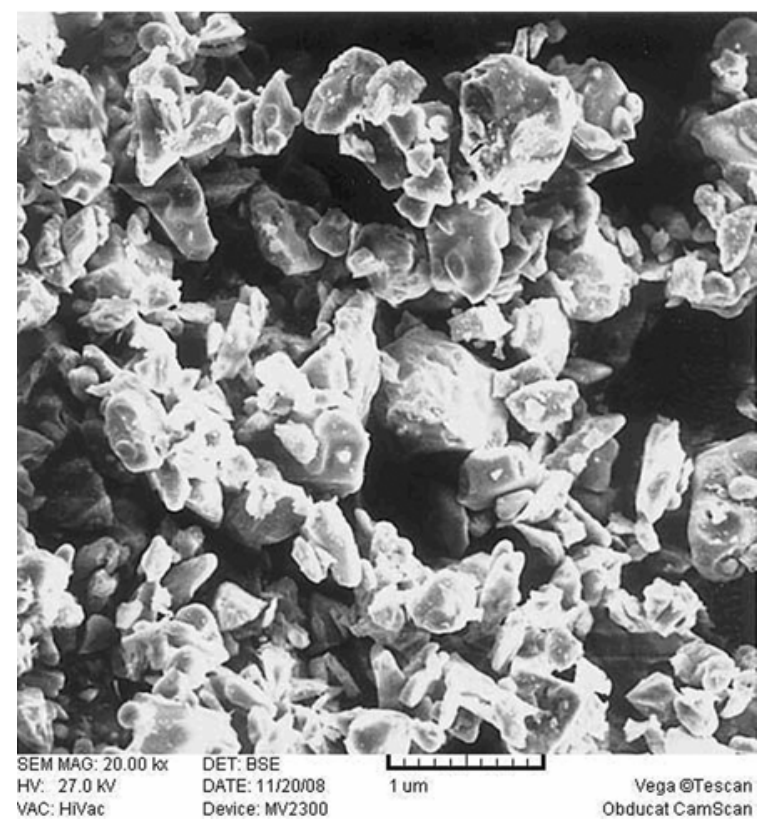

Figure 8. Morphology of $\mathrm{TiB}_{2}$ particles of the sample with the molar ratio of $2 \cdot 3$ heat treated for $1 \mathrm{~h}$ at $1200^{\circ} \mathrm{C}$

This result suggested that there was not enough amount of boron carbide to fully react with titanium dioxide, so all $\mathrm{B}_{4} \mathrm{C}$ and appropriate amount of $\mathrm{TiO}_{2}$ reacted to form $\mathrm{TiB}_{2}$.

Increasing the molar ratio of $\mathrm{B}_{4} \mathrm{C}$ to TTIP to 1.5 , resulted in $33 \%$ more $\mathrm{TiO}_{2}$. As the $\mathrm{B}_{4} \mathrm{C}$ to TTIP molar ratio increased, the diffraction peaks of titanium diboride increased along with a decrease of titanium dioxide peaks. When the ratio reached $2 \cdot 3$, the $\mathrm{B}_{4} \mathrm{C}$ peaks appeared in XRD pattern along with decreasing $\mathrm{TiO}_{2}$ to $17 \cdot 4 \%$ wt and increasing $\mathrm{TiB}_{2}$ to $63.3 \%$ wt. It seemed that there was enough amount of $\mathrm{B}_{4} \mathrm{C}$ to react with all $\mathrm{TiO}_{2}$ but maybe the heat treatment time or temperature was not enough to cause consumption of all reactants. At higher ratio of $2 \cdot 5$, an inverse effect appeared and the intensity of $\mathrm{TiO}_{2}$ peaks increased and the intensity of $\mathrm{TiB}_{2}$ peaks decreased (figure 5).

Figure 6 shows the effect of $\mathrm{B}_{4} \mathrm{C}$ to TTIP molar ratio on weight percent of $\mathrm{TiO}_{2}$ and $\mathrm{TiB}_{2}$ at $1100^{\circ} \mathrm{C}$. Increasing temperature from $1100^{\circ} \mathrm{C}$ to $1200^{\circ} \mathrm{C}$ as the molar ratio is $2 \cdot 3$, resulted in consumption of all reactants and formation of titanium diboride powders. Figures 7 and 8 show the XRD pattern and SEM picture of this sample heated at $1200^{\circ} \mathrm{C}$, respectively.

\section{Conclusions}

Synthesis of titanium diboride powders through a sol-gel method and reduction of hydrolyzed TTIP by boron carbide was studied. Process parameters were optimized to prepare pure $\mathrm{TiB}_{2}$. When a high concentration TTIP was used, the $\mathrm{Ti}(\mathrm{OH})_{4}$ phase nucleated separately on the $\mathrm{B}_{4} \mathrm{C}$ powder surfaces. In the case of low TTIP concentration, required energy for nucleation was not supported, but when the concentration of TTIP was optimum, the mixture of heterogeneous and homogenous nucleation occurred and spherical $\mathrm{Ti}(\mathrm{OH})_{4}$ particles mainly formed on the surface of the $\mathrm{B}_{4} \mathrm{C}$ powders. Using molar ratio of $\mathrm{B}_{4} \mathrm{C}$ to TTIP less than 2.3 caused the partial consumption of titanium dioxide and consequently having the mixture of $\mathrm{TiB}_{2}$ and $\mathrm{TiO}_{2}$ as a main product. Increasing the molar ratio of $\mathrm{B}_{4} \mathrm{C}$ to TTIP more than 2.3 resulted in the formation of $\mathrm{B}_{4} \mathrm{C}-\mathrm{TiB}_{2}$ composite powders. The optimum synthesis temperature was $1200^{\circ} \mathrm{C}$ and pure $\mathrm{TiB}_{2}$ powders could be prepared using molar composition of $\mathrm{Ti}: \mathrm{B}_{4} \mathrm{C}=1: 2 \cdot 3$.

\section{References}

Cushing B L, Kolesnichenko VL and O'Connor C J 2004 Chem. Rev. 1043893

Funk R, Lux B, Schachner H and Tannenberger H 1973 Chem. Abstr. 79

Ge C L and Ye R C 2002 J. Mater Process. Tech. 12414

Greenwood N N 1973 In Inorganic chemistry (eds) J C Bailar Jr, H J Emeleus, R Nyholm and A F Trotman-Dickenson (Oxford: Pergamon Press) Vol. 1

Hwang Y and Lee J K 2002 Mater. Lett. 541

Kim J J and McMurtry C H 1985 Ceram. Eng. Sci. Proc. 6 1313

Krishnarao R V and Subrahmanyam 2003 J. Mater. Sci. Eng. A326 145

Levin L, Frage N and Dariel M P 1999 Metall. Mater. Trans. A30 3201

Matkovich V I 1977 Boron and refractory borides (New York: Springler-Verlag)

Murata Y and Miccioli B R 1971 Am. Ceram. Soc. Bull. 50 182

Radev D D 1996 Metall. 50561

Tjong S C and Chen H 2004 Mater. Sci. Eng. R45 1

Weimer A W 1997 Carbide, nitride and boride materials synthesis and processing (London: Chapman and Hall) pp 641645 